Inna Samoilenko, Anastasija Kamneva. Philosophy management enterprise of energy infrastructure on the basis of social responsibility. Економічний дискурс. 2021. Випуск 1-2. С. 104-110.

DOI: https://doi.org/10.36742/2410-0919-2021-1-11

UDC 339.138

JEL Classification L 220, Q 410

\author{
Inna Samoilenko \\ Doctor of Science (in Economics), Associate Professor, Professor \\ Department of Management \\ National Aerospace University «Kharkiv Aviation Institute» \\ Kharkiv, Ukraine \\ E-mail: samoylbox@gmail.com \\ ORCID: 0000-0002-3623-4998 \\ Anastasija Kamneva \\ Ph.D. (in Economics), Associate Professor \\ Department of Management \\ National Aerospace University «Kharkiv Aviation Institute» \\ Kharkiv, Ukraine \\ E-mail: kamneva_nastia@ukr.net \\ ORCID: 0000-0002-1567-9920
}

\title{
PHILOSOPHY MANAGEMENT ENTERPRISE OF ENERGY INFRASTRUCTURE ON THE BASIS OF SOCIAL RESPONSIBILITY
}

\footnotetext{
Abstract

Introduction. In the age of economic development globalization of the country, for a variety of objective factors, relevant issues regarding social management restructuring and modernization at energy infrastructure enterprises through integration into the energy infrastructure enterprises corporate policy of social standards that would meet the requirements of the modern civilizational world and would have a positive social impact.

Methods. During the implementation of the research tasks were used the as follows: cognition method, combination of general scientific and special research methods, the analysis and synthesis, the historical and logical method, the induction and deduction, which made it possible to separate and clarify the social and economic essence of definitions sush as "corporate social responsibility" and find out and define the principles and instruments of social responsibility at an enterprise.

Results. The article is concerned with development of approaches interpreting the social and economic essence of "corporate social responsibility" for energy infrastructure enterprises, which is manifested in the social, economic and cultural life of citizens and is based on the principles of honesty, sociability, transparency and responsibility.
} 
Discussion. Another task that must be solved and which requires its separate scientific research is the formation of a policy for reducing energy poverty. In this context, taking into account world experience it is necessary to investigate existing approaches to interpreting vulnerable categories of consumers and identify groups of socially vulnerable consumers.

Keywords: corporate social responsibility, energy infrastructure enterprises, social standards, service quality, consumers.

\section{Introduction.}

In the age of economic development globalization of the country, it is extremely important to update the entire socio-economic system based on the provision of such standards as responsibility, corporate community, dynamism, tolerance, high sociability and others. According to a number of objective factors, relevant to the social management restructuring and modernization at energy infrastructure enterprises through integration into the corporate policy of energy infrastructure enterprises of social standards that would meet the requirements of the modern civilization world, high social living standards would contribute to the development of energy infrastructure companies and have a positive social impact.

Recent research analysis. A series of scientific studies [1-4] and the existence of numerous programs, projects, memorandums, in particular, International Standard ISO 26 000: 2010 "Social Responsibility Guide" [5], Standards for Social and Ethical Reporting Series AA 1000 (Accountability 1000) International Standard for Assessing Social Aspects of SA 8000 Management Systems (Social Accountability 8000), Memorandum on Social Responsibility Business in Ukraine [6], "On the Community of Good Corporate Citizen" [7] serve in favor of this issue and testify to the interest of the community (both world and national) to the topic of social responsibility integration in the enterprises activities and corporate structures.

For this reason, the study of issues of social responsibility during civil society and integration processes into the world community is the relevant study interest.

\section{Purpose.}

The purpose of the article is deepening theoretical and methodological basis and developing practical recommendations for the development of social responsibility in the activities of energy infrastructure enterprises.

\section{Methods.}

The use of such methods as cognition method, combination of general scientific and special research methods, the analysis and synthesis, the historical and logical method, the induction and deduction, which made it possible to separate and clarify the socio-economic essence of definition as "corporate social responsibility" and find out and define the principles and instruments of social responsibility at an enterprise.

\section{Results.}

The cut-off point in the study of social responsibility (SR) is clear regulation of the term content. According to Professor Sara S. Sejs, before progressing to methodologies that are inherent in cost estimates, it is originally important to try to define the concept. ("It is important to attempt to define the concepts before progressing to appropriate valuation methodologies")

Since the 1970s, the term SR has been used in international practice to define the company's voluntary commitments to improve the quality of living and work of both employees and society and the environment as a whole. This term does not replace the concept of "virtue" and "public activity", with which the company confidently deserves the trust of employees and consumers. SR is a deeper concept owing to which an enterprise may, first of all, provide stable and reliable conditions for the development of its own business $[8,9]$. 
According to number of sources $[4,8,9] \mathrm{SR}$ is the voluntary activity of private and public sectors aimed at compliance with high standards of operational and production activities, social standards and quality of work with staff, minimization of harmful impact on the environment in order to equalize the existing economic and social disproportions; creation of trusting relationships between business, society and state; improvement of business performance and profitability indicators over the long term.

The creators of this work consider corporate social responsibility as activities aimed primarily at consumers, employees, state and society as a whole; as an organization activity that is responsible for the impact of its decisions and actions to the living standard of Ukrainian society and improving the environment; as an activity organization that by realizing transparent, honest, open and ethical behavior, promotes sustainable development, including health and well-being of people, takes into account the interests of society and expectations of parties involved, implements social responsibility programs related to the support of vulnerable segments of the population and works for the long term in accordance with the current legislation and international norms of behaviour.

Social responsibility in the activities of energy infrastructure enterprises is based on such principles as:

- accountability and transparency suggests that the company is responsible to those who are influenced by its decisions and actions, as well as to society as a whole, for the general influence on the decisions and activities of the company to society;

- ethical behavior lies in virtue, decency (not to receive income with violation of professional ethics rules); respect for all Ukraine laws and market rules (to run your business honestly);

- respect for parties involved. The main components of this principle are decency, honesty, sociability and trust. Priority direction is consumer satisfaction. Management is value-oriented for shareholders. Main efforts are aimed at constant improvement of the employees living standards;

- observance of the rule of law means honest, strict adherance to the requirements of the Ukrainian laws. The rule of law is mandatory in the day-to-day running of an enterprise;

- respect for human rights means that basic values and human dignity come first;

- environmental care, security and health. The postulates of this principle are environmental protection in all business activities; ensuring safe working conditions for staff members; comfortable working environment and social protection of employees in order to maintain health. Support for environmental protection programs allows not only to increase the company image among the community, but also fully helps the company to realize the slogan: "Ecological means economical!".

- established relations with society. The responsibility and obligation of the company before the community are main thing. Improving the living standards, volunteering, charity, assistance in the event of a natural disaster is the principle on which each company's new model of success is based.

According to the United Nations [2, c. 9], 75.8\% of corporate structures in Ukraine are engaged in implementing programs in the field of social responsibility. In this regard, it is extremely important to develop new, effective mechanisms on the implementation of the concept of socially responsible marketing in the energy infrastructure enterprises activities which not declarativly, and at the level of real affairs brought Ukrainian citizens the benefits of building civil society, comply with current legislation and conform to international norms of behaviour.

"Modern consumers are no longer attracted by the value of formal declaration. Nowadays, it is important for consumers to protect their interest in solving their problems, not only to make the progress of the enterprise, but to change the world around them for the better. In the time of informatization of society by a domestic enterprise, it is important to objectively prove their affiliation with the supporters of sustainable development [10]."

A distinctive feature of a modern advanced country is to meet the needs of its citizens. Moreover, the growth of living standards entails increasing needs of the population, whose satisfaction is directed to the activities of business entities, including energy companies. Satisfaction of the needs of citizens in 
electricity is carried out in the electricity market where both economic entities (producers and sellers) and consumers need appropriate protection.

Growth of attention to meeting the consumer's needs and society interests requires a company to develop and introduce new approaches to fulfilling its traditional functions, harmonization of interests of the company and interests of society, the establishment of strong partnerships with consumers, quality and high standards of consumer services.

Taking in consideration the above, following the basic principles and provisions of responsible marketing that proposed Patrick Byers [11], based on the postulates of the "Global Reporting Initiative (GRI) by definition of which there are issues and indicators reflecting significant social, economic and environmental companies implications that can greatly affect the behavior parties involved or to the company itself [12], which are essential for business." The creators of the work have considered directions to increase the protection of consumers' interests by legislative consolidation of quality service standards for energy services and responsibility measures for their non-compliance.

It should be emphasized in the liberalized energy market consumer rights protection is carried out taking into account the mutual influence of three factors:

- market competition, which forces suppliers to offer the best prices and quality of services to consumers;

- regulatory control of power companies to ensure the reliability and electricity quality for all consumers at affordable prices;

- impact of consumer associations representing and protecting consumers' interests on regulatory and suppliers.

For this reason, regulation of energy services quality in the national market of energy infrastructure enterprises can be carried out using such measures:

- active consumer participation in consulting or companies supervisory boards, organization of hot quality service lines, appointment of the authorized consumer rights (measures aimed at solving conflict issues);

- definition of minimum limits from certain aspects of activity, violation of which entails impending fines and reducing tariffs (measures aimed at establishing minimum standard activities);

- installation of energy services target quality indicators, which entails the imposition of fines, and exceeds lead to financial remuneration (application of stimulatory measures);

- installation of requirements for publishing information about the performance indicators of the energy supply company (ESC), which enable the creation of external pressure and to stimulate the ESC to resolve quality issues.

In accordance with international standards for the reliability assessment and energy services quality (act as components of the standard of energy situation sustainability) ESC is determined by the effect for end users. ESC for many consumers is a "single window" in power. Due to this precise reason the consumer assesses the transformation in the industry by quality of energy services, the efficiency of the functioning of the energy sector, tariffs fairness and often the work of the authorities. In view of this, regulation should be directed to the quality energy services indicators that are firstly important for the consumer, and secondly can be monitored by ESC and, thirdly, can be quantified by the regulator.

Evaluation concerns primarily as aspects of energy services quality as continuity of electricity supply or reliability (energy safety factor) of electricity supply (number and frequency of disconnections); technical quality (physical characteristics of electricity supplies, for example, voltage changes); commercial quality (quality of relations between companies and consumers, for example, complaints from consumers, responding time to consumer complaints, etc.).

As mentioned above, to build a reliable and objective system for assessing the reliability and quality of energy services requires regular feedback from consumers, which is possible, provided the formation of a responsibility system of the energy company for compliance with individual indicators of reliability and energy service quality. Formation of such a system, from one's end, requires the 
development of the relevant methodological basis and governing document, in particular the Provisions on the responsibility of the ESC for compliance with the individual indicators of reliability and energy services quality.

The Provision referred to, which is to regulate the procedure for establishing a violation of certain reliability indicators and energy services quality for transmitting electric energy, the procedure for verifying the fact of individual indicators violation of reliability and quality of transmission of electric energy, compensation procedure for violation of individual reliability indicators and energy services quality for transmitting electricity, as well as regulate issues related to the onset of network organizations responsibility for violation of individual indicators of reliability and electricity transmission services quality. Approbation of the developed Provision involves conducting an experiment in one of the regions. The objectives of the experiment are:

- determination of the methods effectiveness for stimulating the level of reliability and energy services quality for electricity transmission;

definition of the effectiveness of the use of technical and organizational decisions on the system organization of network organizations responsibility for compliance with certain indicators of reliability and electricity transmission services quality;

- determination of the compensation size (commercially feasible size) for violation of certain reliability indicators and energy services quality for transmitting electric energy;

development of the results of the implementation of the experimental legal acts aimed at introducing a network organizations responsibility system for observing certain reliability indicators and energy services quality for electricity transmission.

In general, the practical implementation of the social responsibility principles in the activities of energy infrastructure enterprises is carried out through the philosophy of five main aspirations for social responsibility:

1) a company for its consumers. The modern enterprise management concept set a new philosophy of interaction with consumers which is the formation between the company and the consumer of a transparent environment, trust and productive relations. The growth of the company's attention to customer service requires the service high standards introduction, establishing new approaches to the quality of traditional functions by each employee, understanding by each specialist in its proactive behavior in managing the process of interaction with the consumer;

2) a company for its employees. This is the situation when the company is guided not only to effectively implement human resources management processes, but also creates an environment that opens up new opportunities for development, stimulates new initiatives and achievements, is interesting for daily activities;

3) a community company. This is the situation when support of cultural traditions is one of the key elements of social investment. This contributes to the enterprise popularization not only at the level of the region and the country, but also beyond its borders;

4) a company for the environment (eco-company). An important characteristic of social responsibility is the desire to implement social and environmental issues in its decision making process and be accountable for influences that these decisions and actions are made to society and the environment;

5) a company is reliable and secure. The energy enterprises specificity is associated with a dangerous product, which is why the risk reduction is a priority for the enterprise.

In summary it can be noted that the strong part of the social-responsibility implementation in the energy infrastructure enterprises activities is the harmonization of relations and the establishment of partnerships between energy infrastructure enterprises, consumers, governmental structures and public. Energy infrastructure enterprises receives increasing the consumer confidence level in the company activities, its products and services; compliance with international norms, principles and standards; confidence of foreign investors and their loyalty; improvement of business reputation and company 
image, providing public reputation; improving energy infrastructure and improving financial and economic performance, receiving interested parties information that can help in improving business processes; stability and sustainable existence of the company in the long run.

In addition, the security of energy infrastructure is strengthened and there is infrastructural provision of the necessary volumes of services for keeping the tariff at an acceptable level.

Consumers receive available, reliable, efficient, qualitative, environmentally safe, duly regulated and socially accepted energy services, as well as a substantiated tariff policy that provides for the availability of electricity to all groups of the population.

Society and state receives improvement and development of the Institute for Consumer Protection; development and legal consolidation of legal behavior mechanisms under legislative and contractual values and corporate values; provision of social well-being, transparency and generality of information on the state of the energy infrastructure subjects, strengthening of relationships of energy infrastructure subjects with the public and cooperation between key participants in the process; ensuring the balance of consumer interests, society and state and their mutual responsibility; stimulating innovation activity and opportunities for supporting investment programs and innovative projects of energy infrastructure subjects; responsible corporate governance and new opportunities for the economic, social and cultural country prosperity.

The weak side is that social responsibility within our society is more subject to scientific research and discussions than the norm and regulator of public life. In addition, the lack of legislative regulation and information closeness of most Ukrainian energy infrastructure enterprises for the general public (detailed information on the internal and external activity of the enterprise is closed). In energy, practice has been performing an activity, breaking someone else's and without protecting their rights.

The lack of clear procedures that allow you to realize the right to access information and the right to participate in the adoption of significant decisions leads to the fact that the realization of consumers' right to access to justice is actually complicated. In order to ensure transparency in the functioning of the energy sector, legislation exists, but it does not have productive mechanisms of execution. Without the designation of specific mechanisms for implementing these rights, as well as without the legislation provided for in the legislation for non-fulfillment, these norms of legislation become formal and do not give a civil society and the regulatory body to implement effective control over the energy sector.

Opportunities are international experience on issues: What are the minimum consumer service standards for energy-consumer companies? How do modern technologies in the framework of socialliability affect the organization of work with consumers (collection of payments, notification, organization of commercial accounting)? What are the best international practices in serving consumers? What are the international standards of social responsibility and regulations in the field of consumer protection and vulnerable segments of the population?

Threats in preventing successful implementation of such projects are the following factors as:

- there are no incentives to improve the quality of energy services (the regulatory company is mainly focused on the requirements of the regulatory body, rather than consumers);

- there are no mechanisms for stimulating energy infrastructure to optimize investment activity (available tariff policy "Costs PLUS" in the field of transmission and electric energy supply is ineffective, since it does not create incentives to reduce operating costs and energy companies losses, does not form investment attractiveness of the industry, does not stimulate the development of the economy and social sphere. It ought to be noted that the substantiated tariff policy provides for the availability of electricity to all layers of the population and is a guarantor for the population);

- there are no instruments of an institutional nature (lack of an organ that could introduce mechanisms for public control with consumer participation).

Taking into account the above, analyzing the social responsibility principles at energy infrastructure enterprises, it can be argued that social responsibility, in the present conditions, is a prerequisite, which leads to financially profitable business and sustainable development both the company 
and the state as a whole. Implementation of corporate social responsibility should be carried out in 4 directions: (1) corporate management standards; (2) staff members; (3) society; (4) environment, which in turn indicates a strategic approach to social responsibility and its implementation. In addition, it should be noted that the policy and strategy of enterprise social responsibility must be closely related to the company's development strategy, as energy infrastructure enterprises are part of society in general and territorial community in particular.

It should be noted that the transition to an active social responsibility policy requires a modern approach and new requirements for the formation of a new energy policy paradigm at the enterprise based on the principles of transparency (ensures transparency of receiving information to consumers about the energy prices level and the quality of received energy services, as well as monitoring societies for energy flows; environmental friendliness (means impending harm to the natural environment, that is, reflects the need for environmental protection measures during the implementation of energy projects); sovereignty (gives a real possibility of consumers to become a full-fledged entity of energy market (to influence the price level of demand) and social responsibility.

The phased implementation of social-responsibility in the energy infrastructure enterprises activities can become a source of powerful growth in the energy sector and significantly increase the consumer's welfare.

Conclusions. The meaning of the term corporate social responsibility for energy infrastructure enterprises is defined, which is reflected in the social, economic and cultural life of citizens and is based on the principles of honesty, sociability, transparency and responsibility. Because of the fact that energy infrastructure companies are part of society in general and the local community in particular, they must respond to the public order, setting the right example, ensuring human dignity, the rule of law and responsibility in their territory and outside their personal location.

Another task that must be solved and which requires its separate scientific research is the formation of a policy for reducing energy poverty. In this context, taking into account world experience it is necessary to investigate existing approaches to interpreting vulnerable categories of consumers and identify groups of socially vulnerable consumers.

\section{References}

1. Zinchenko, A.H., \& Saprykina, M.A. (2010). Korporatyvna sotsialna vidpovidalnist 2005-2010: stan ta perspektyvy rozvytku [Corporate social responsibility 2005-2010: state and prospects of development]. Kiev: Vyd-vo «Farbovanyi lyst».

2. Lazarenko, O., \& Kolyshko, R. (2008). Bazova informatsiia z korporatyvnoi sotsialnoi vidpovidalnosti [Basic information on corporate social responsibility]. Kiev: Vyd-vo «Enerhiia». [Publishing house "Energy"].

3. Baron, S., Field, J., \& Schuller, T. S. (2000). Social capital : Critical perspective . Oxford University Press.

4. Chatterii, A., \& Levine, D. How Well Do Social Ratings Actually Measure Corporate Social Responsibility. Retrieved from http://www.hbs.edu/faculty/Publication\%20Files/07-051.pdf.

5. ISO 26 000: 2010. Retrieved from http://znaimo.com.ua/ISO_26000.

6. Sotsialna vidpovidalnist biznesu: rozuminnia ta vprovadzhennia. Retrieved from http://www.un.org.ua/files/Concept_Paper.pdf.

7. Pro spilnotu SVB. Retrieved from http://svb.ua/about.

8. CSR indices worldwide. Retrieved from http://www.odpowiedzialni.gpw.pl/csr_indices_worldwide.

9. Socially-Responsible Investing. Retrieved from

http://www.odpowiedzialni.gpw.pl/socially_responsible_investing.

10. Vidpovidalnyi marketynh. Haid dlia kompanii [Responsible marketing. Guide for companies]. (2012). Kiev: Vydavnychyi dim «ADE F-Ukraina».

11. Patrick Byers. The Responsible Marketing Blog. Retrieved from http://responsiblemarketing.com/blog/about-patrick-byers.

12. GRI Implementation manual. (2015). Retrieved from https://www.globalreporting.org. 